\title{
中学生期におけるトップ野球選手の成熟度
}

\author{
勝亦 陽一 $^{1}$ 設楽 佳世 $^{2} \quad$ 飯田悠佳子 ${ }^{3}$ \\ 鳥居 俊 ${ }^{4}$ 高井 洋平 ${ }^{5}$ 平野 裕一 $^{6}$

\section{Characteristics of biological maturity in top junior baseball players}

\section{Yoichi Katsumata ${ }^{1}$, Kayo Shitara ${ }^{2}$, Yukako Iida ${ }^{3}$, Suguru Torii $^{4}$, Youhei Takai $^{5}$ and Yuichi Hirano}

\begin{abstract}
The purpose of this study was to clarify the biological maturity of top junior baseball players in relation to Peak height velocity (PHV) ages and birth month. The subjects were 25 junior high schools (TOP) with high competition level and 30 standard baseball players (BB). Using the proportional distribution method, the PHV age was calculated as an index of biological maturity. Consequently, the PHV age of TOP group (12.3 \pm 0.7 years) was significantly lower than the BB group ( $13.0 \pm 0.8$ years). The birth month distribution was different between the two groups. $84 \%$ of the TOP group and $56 \%$ of BB group were born between April and December, suggesting that TOP group matures earlier than the BB group by 0.9 years.
\end{abstract}

Key words : biological maturity, baseball, junior high school students, peak height velocity, birth month 生物学的成熟度，野球，中学生，PHV 年齢，生まれ月

\section{I 緒言}

競技力の高い選手を育成するには，スポーツ種 目にあった身体適性を備えた人材を発掘すること が重要である．野球競技は，日本の中でも競技人 口が多く，小・中学生期の世界大会や全国大会で 勝利するために競技力の高い選手を選抜すること も多いことから，ジュニア選手の選抜基準は大き
な課題である.

野球競技において, 速いボールを投げることは, 試合の勝敗を大きく左右する投手だけでなく，い ずれのポジションにおいても重要な能力である. リトルリーグに所属する野球競技選手を対象に投 球スピードと身長との関係を縦断的に検討した石 田（2003）は，身長の増加に応じて投球スピード が速くなることを報告している。また，投球エネ

\footnotetext{
東京農業大学

国立スポーツ科学センター

駿河台大学

${ }^{4}$ 早稲田大学

${ }^{5}$ 鹿屋体育大学

${ }^{6}$ 法政大学

${ }^{1}$ Tokyo University of Agriculture

${ }^{2}$ Japan Institute of Sports Sciences

${ }^{3}$ Surugadai University

${ }^{4}$ Waseda University

${ }^{5}$ National Institute of Fitness and Sports in KANOYA

${ }^{6}$ Hosei University
} 
ルギーを予測する体力要素は, BMI, 立ち幅跳び, $10 \mathrm{~m}$ スプリントタイムおよび握力（Nakata et al., 2013）である。このような背景から，ジュニア野 球選手を発掘する基準は, 競技力に直接的に関係 している投球スピード，およびそれに関連する体 力要因とすることが多い. しかしながら, 中学生 期の男子は，身長の年間変化量が最も大きい（三 野・成山, 1996) ため, 生物学的な身体の成熟度 （以下，成熟度とする）にも大きな個人差がある. また, 成熟度は, 運動能力（Beunen et al., 1981） および筋力の発達（松浦, 1977）に影響すること から，ジュニア選手を評価・育成する基準として， 成熟度を考慮する必要がある。

Jリーグアカデミーに所属するジュニアサッ カー選手を対象とした研究では, 競技レベルの高 い男子サッカー選手の骨年齢から評価した成熟度 が平均もしくは早熟傾向にあること示している (広瀬・平野, 2008). 一方, ジュニア野球選手を 対象に, 身長の縦断的資料から成熟度を検討した 調査によると, 中学生男子野球選手の身長が最も 増加する（Peak height velocity：PHV）年齢は, 12.9 歳であり, 日常的にスポーツを行っていない 中学生男子と有意な差がない (三野・成山, 1996). しかしながら,この研究では対象とした選手の競 技レベルが明らかにされていない. 以上のよう に, ジュニア野球選手の成熟度と競技レベルとの 関連についてはこれまでのところ明らかにされて いない.

日本の野球競技では，基本的に年齢層別（小． 中学校および高等学校別）に大会が開催される. そのため, 特に同学年内における生まれ月の相違 は, 大会時の暦年齢だけでなく, 成熟度の個人差 に影響を与える。生まれ月の相違が運動能力差お よび選手選抜に与える影響 (相対的年齢効果) は, 発育期において大きく，年齢を重ねるほど小さく なると考えられる。しかしがら，プロ選手の生 まれ月には偏りがあり,特に 4-9月に多い(岡田, 2004)。 また, 野球は, 日本において競技人口が多 い競技の一つであるが, 相対的年龄効果は, 競技 人口が多いほど現れやすい（Musch and Grondin, 2001). 以上の結果を考慮すると, 競技力が高い 発育期の男子野球選手では, 生まれ月に偏りがみ られる可能性が高い. そのことは競技力の異なる
選手間の身長の相違を生む要因となる可能性があ る. 発育期の野球選手では身長の増加と投球ス ピードの増加に関連がある（石田，2003）ことを 考慮すると, 競技レベルの高い野球選手の成熟度 を生まれ月の観点から明らかにすることは，選手 を選抜していくうえで重要な資料となる。しかし ながら，これまでに発育期の競技力が高い男子野 球選手の生まれ月分布, さらには成熟度との関連 から検討した例はない.

以上のことから, 本研究は, 中学生期の競技力 が高い男子野球選手（トップ野球選手）の成熟度 について, PHV 年齢および生まれ月の観点から明 らかにすることを目的とした。

\section{II 方 法}

\section{1. 被検者}

55 名の中学生男子野球選手を対象とし, 競技成 績を基準に 2 群に分けた. 1 つは中学全国大会に 出場した投手 25 名（TOP 群）とした. TOP 群は, 市区町村の選抜チームに選出され, 全国大会に出 場した投手，または中学校単位のチームとして全 国大会に出場した投手のいずれかであった，TOP 群の投手は，相手に得点を与えない，試合に勝利 するための高い競技力を有していると判断できる ため, 中学期の男子野球選手の中で, 競技成績お よび競技力ともに最も優れた野球選手と考えられ る. 一方, TOP 群の対象群は, 野球競技経験が 2 年以上かつ都道府県以上の大会に出場していない 野球選手 28 名（BB 群）とした。被検者の身体特 性，年齢，競技開始年齢および投球スピードを表 1 に示した。 なお, 競技開始年齢は, TOP 群と $\mathrm{BB}$ 群との間に有意な差がみられなかった。ま た，BB群の身長，体重，投球スピードおよび $\mathrm{PHV}$ 年齢について, 対象者の少なかった捕手を除 いてポジション間の比較を行ったが, 統計的に有 意な差はみられなかった。

本研究では，すべての被検者および保護者に研 究の目的および意義について書面による説明を 行った上で研究参加への同意を得た。また，本研 究の実施については, 選手が所属するチームの監 督または部長に同意を得た。本研究の実施につい ては東京農業大学の倫理委員会の許可を得た。 
表 1 被検者の年齢, 競技開始年齢, 身体特性および投球スピード

\begin{tabular}{|c|c|c|c|c|c|c|}
\hline 群 & TOP & BB & & & $\begin{array}{l}\text { 3B 群 } \\
\text { ション別 }\end{array}$ & \\
\hline ポジション & 投手 & 全体 & 投手 & 捕手 & 内野手 & 外野手 \\
\hline n & 25 & 28 & 7 & 2 & 13 & 6 \\
\hline 年齢（歳） & $14.7(0.3)$ & $14.5(0.3)$ & $14.7(0.3)$ & $14.8(0.2)$ & $14.3(0.3)$ & $14.6(0.3)^{*}$ \\
\hline 競技開始年齢（歳） & $8.2(1.4)$ & $8.7(1.8)$ & $8.4(1.5)$ & $7.5(1.4)$ & $8.9(2.0)$ & $9.0(1.8)$ \\
\hline 身長（cm） & $173.4(5.0)$ & $168.0(6.4)$ & $168.4(6.7)$ & $176.8(2.4)$ & $166.9(6.8)$ & $167.0(4.5)^{*}$ \\
\hline 体重（kg） & $66.3(6.3)$ & $55.5(8.5)$ & $56.3(7.2)$ & $59.5(7.8)$ & $55.6(8.3)$ & $52.8(11.5)^{*}$ \\
\hline PHV 年齢（歳） & $12.3(0.7)$ & $13.0(0.8)$ & $12.8(0.5)$ & $13.5(0.2)$ & $12.9(1.1)$ & $13.1(0.7)^{*}$ \\
\hline 投球スピード $(\mathrm{m} / \mathrm{s})$ & $34.5(1.6)$ & $29.9(2.5)$ & $31.7(1.6)$ & $31.1(0.8)$ & $29.0(2.8)$ & $29.2(1.8)^{*}$ \\
\hline
\end{tabular}

* : 群間に有意な差 $(p<0.05)$

年齢は中学 3 年生 4 月時の值, 身長および体重は, 投球スピードの計測時期の值を記載

\section{2. 身長および生まれ月の調査および投球ス ピードの計測}

被検者には, 6-14歳の間における身長の縦断的 データおよび生年月日を調査用紙に記入するよう 指示した. データは, 毎年度 4 月以降に各学校で 実施している健康診断での測定結果とし， $0.1 \mathrm{~cm}$ 単位で記入させた，投球スピード計測時の身長 は，BB 群では実測した。一方，TOP 群は実測が 困難だったため, 被検者に学校の保健室で計測す るよう指示した.

競技力の指標として投球スピードを計測した. TOP 群は, 中学生を対象に軟式 B 号球を使用し て行われる全国大会（8月）において測定した. バックネット毫から投手が投じたボールのスピー ドをスピードガン (PSX-2, Decatur 社製) により 計測した。ストレート系のボールを 5 球計測し, 先行研究と同様, 最も速かった 1 球を個人の投球 スピードとした（比留間・尾縣, 2011 ; 勝亦ほか, 2008)。なお, 疲労を考慮し, 投手が試合に登板し た直後からの 5 球を計測した．BB 群の被検者に は十分なウォーミングアップを行わせた後, 平地 においてワインドアップポジション，またはセッ トポジションから $18.44 \mathrm{~m}$ 前方に位置したネッ トに向かって全力でボール投げを行わせた。 ス ピードガンはネット毫に設置した. 本研究では投 球した場所が TOP 群 (マウンド) と BB 群 (平地) で異なる。しかしながら, 本研究と同年齢の野球 選手を対象とした研究によると，マウンドでの投 球スピードと平地での投球スピードとの間に統計 的に有意な差は示されない（Nissen et al., 2013） ことから, 投球した環境の影響は小さいと考えら
れる. 球数は 5 球とし, TOP 群と同様, 最も速 かった 1 球を個人の投球スピードとした. ボール は, 学童用の軟式 B 号球 (重量 : $135 \pm 1.8 \mathrm{~g}$, 直

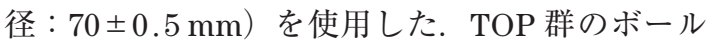
スピード計測は, 全日本少年軟式野球大会にて実 施した. 大会を主催する全日本軟式野球連盟に は，ボールスピードの調査およびデー夕公開につ いて了承を得た。なお, 身長, 生まれ月の調査お よび投球スピードの計測は, 対象者が中学生 3 年 生 6-9 月の間に行った.

\section{3. 分析方法および統計処理}

身長の年間変化量を算出し, 身長の年間変化量 が最も大きい (Peak height velocity : PHV) 年齢を 比例配分法（松本ほか, 1988 ; 三野・成山, 1996) により算出した。比例配分法は, 身長の值を過去 にさかのぼり PHV 年齢を算出する方法として, 作図法, 関数法に劣らない精度があることが報告 されている（松本ほか, 1988). なお, TOP 群 1 名 および $\mathrm{BB}$ 群 10 名の選手は, 14 歳時（中学 3 年 生の 4 月）に PHV 年齢に達していなかったため, 15 歳時（高校 1 年生の 4 月）の身長を追加で調査 し, PHV 年齢を算出した。 また, 身長の年間変化 量とは別に, 小学校 1 年生 4 月から中学校 3 年生 4 月まで, および中学校 1 年生 4 月から中学校 3 年生 4 月までの身長変化量を算出した（身長変化 量 (小 1-中 3), 身長変化量 (中 1-中 3) ).

PHV 年歯, 身長変化量 (小 1 -中 3 ), 身長変化量 （中 1-中 3）の群間比較には対応のない $\mathrm{t}$ 検定を 用いた。また，各年齢における身長の比較には， 2 要因（群間（TOP 群および BB 群 $) \times$ 年齢間 $\left(6^{-}\right.$ 


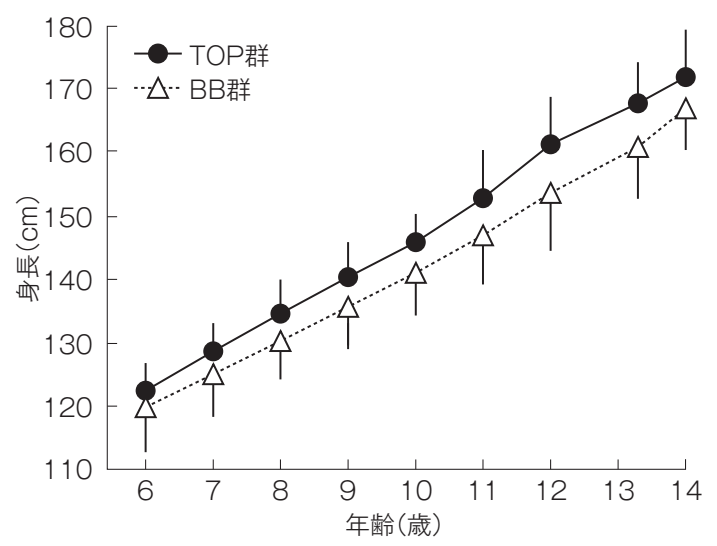

図 1 身長の縦断データにおける TOP 群および BB 群 の比較

群間（TOP 群と BB 群との間）に主効果（ $p<0.05 ）$
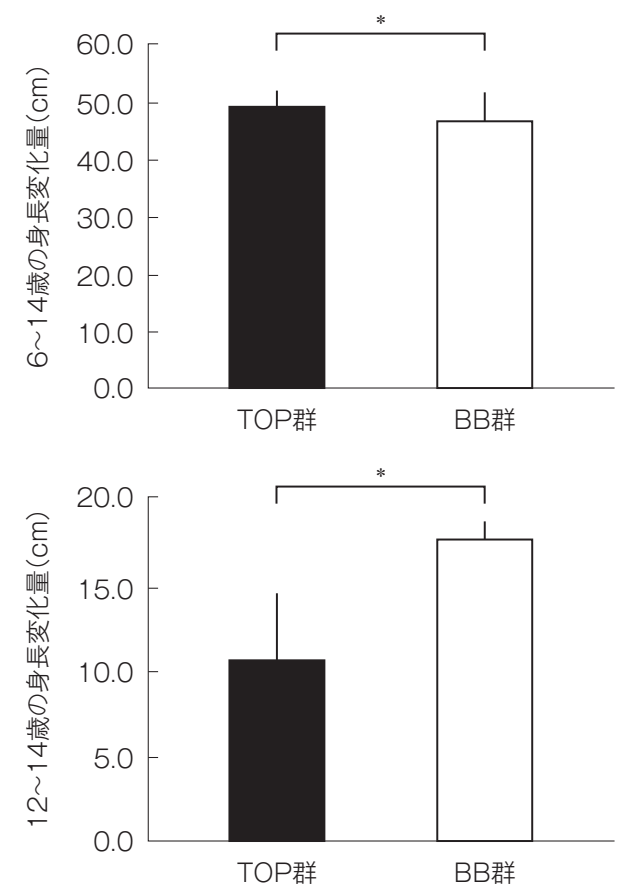

図 3 身長変化量における TOP 群と BB 群の 比較

群間に有意な差 $(*: p<0.05)$

14 歳)）の分散分析を行い, 交互作用および主効 果の有無を確認した。分散分析の結果, $\mathrm{F}$ 值が有 意である場合は, Bonferroni 法を用いて年齢間差 の有意性を検定した。

生まれ月の分析方法は岡田（2004）と同様とし た.すなわち 3 力月毎の人数を算出し全体数で除

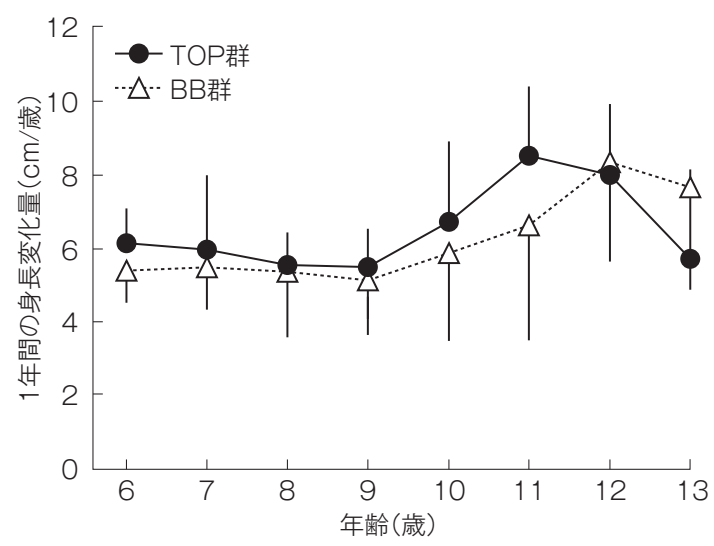

図 21 年間の身長変化量における TOP 群と BB 群の 比較

交互作用あり（2 元配置の分散分析 $(p<0.05))$

すことで全体に対する 3 カ月毎の割合を算出し た. 月間 $\left(3\right.$ カ月毎) の比較には $\chi^{2}$ 検定を用いた. 本研究は, すべての統計処理について危険率 5\%未満をもって統計的に有意とした．統計量の 算出には, 統計処理ソフト (IBM SPSS Statistics version22.0）を用いた.

\section{III 結 果}

各年齢における身長を図 1 に示した。 2 要因 (群間 $(\mathrm{TOP}$ 群, BB 群) $\times$ 年齢間 (6-14 歳)) の分 散分析を行ったところ, 交互作用は認められな かったが，群間および年齢間に主効果が認められ た. 各年齢の身長は, TOP 群が BB 群よりも 3-7 $\mathrm{cm}$ 高值であった。

各年齢における身長の年間变化量を図 2 に示 した. 2 要因 (群間 (TOP 群, BB 群) $\times$ 年齢間 $\left(6^{-}\right.$ 14 歳)）の分散分析を行ったところ, 交互作用が 認められた。また，身長変化量（小 1-中 3 ）およ び身長変化量（中 1-中 3) の群間比較を行ったと ころ, 身長変化量 (小 1-中 3) では, TOP 群 $(49.2$ $\pm 2.6 \mathrm{~cm})$ が $\mathrm{BB}$ 群 $(46.8 \pm 5.1 \mathrm{~cm})$ よりも有意 に高值であった（図 3)。一方, 身長変化量 (中 1中 3) では, TOP 群 $(10.7 \pm 3.9 \mathrm{~cm})$ が BB 群 $(17.6$ $\pm 5.1 \mathrm{~cm})$ よりも有意に低值を示した. PHV 年 齢は, TOP 群が $12.3 \pm 0.7$ 歳であり, BB 群の $13.0 \pm 0.8$ 歳よりも有意に低值を示した（図 4）. 投球スピードは TOP 群が $34.5 \pm 1.6 \mathrm{~m} / \mathrm{s}$ であ 


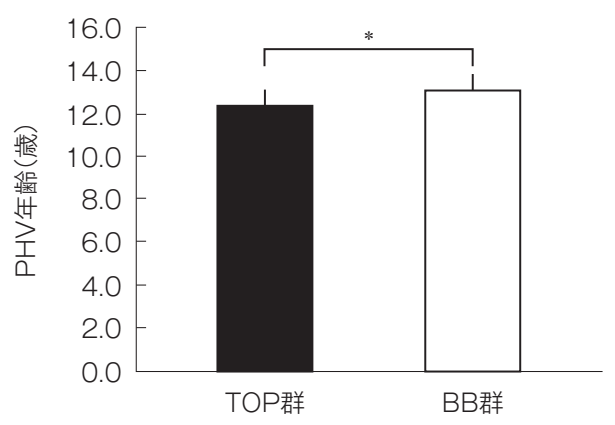

図 $4 \mathrm{PHV}$ 年齢における TOP 群と BB 群の 比較

群間に有意な差 $\left({ }^{*}: p<0.05\right)$

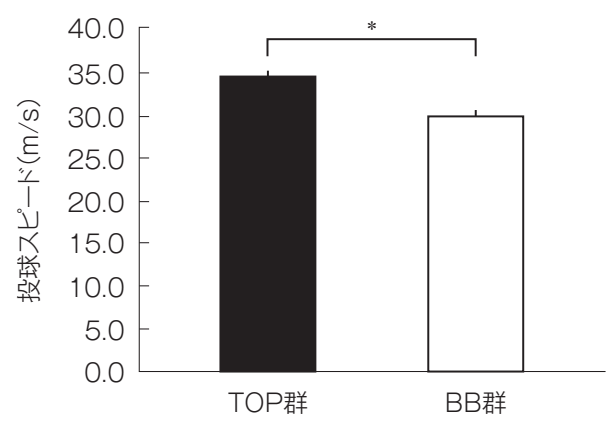

図 5 投球スピードにおける TOP 群と BB 群 の比較

群間に有意な差 $(*: p<0.05)$

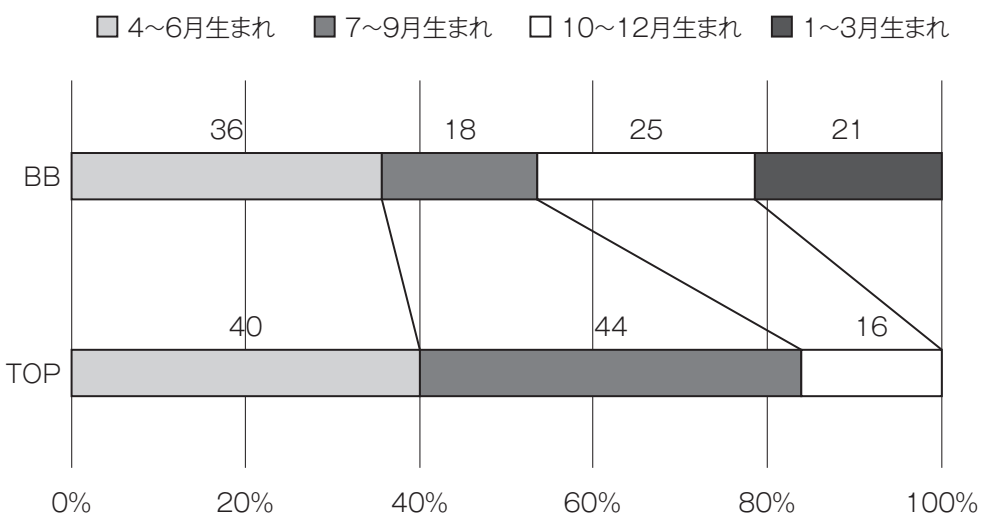

図 6 TOP 群および BB 群における生まれ月の分布

群間に有意な差 $(p<0.05)\left(\chi^{2}=8.92\right)$

り, BB 群の $29.9 \pm 2.5 \mathrm{~m} / \mathrm{s}$ よりも有意に高值で あった（図 5)。なお，投球スピード計測時の身長 は, TOP 群が $173.4 \pm 5.0 \mathrm{~cm}$, BB 群が $168.8 \pm$ $6.2 \mathrm{~cm}$ であり TOP 群が有意に高值であった.

図 4 に $\mathrm{TOP}$ 群と BB 群の生まれ月の分布を示 した. TOP 群の生まれ月は 4-6月が 40\%，7-9 月 が 44\%，10-12 月が 16\%，1-3 月は 0\%であった. 一方，BB 群では 4-6月が 36\%，7-9 月が 18\%, 10-12 月が $25 \% ， 1-3$ 月は $21 \%$ であた（図 6). $\chi^{2}$ 検定の結果, TOP 群と BB 群との間には有意な 差が認められた $\left(\chi^{2}=8.92\right)$.

\section{IV 考察}

本研究の目的は, 中学生期のトップ野球選手に おける成熟度について, PHV 年齢および生まれ月 の観点から検討することであった。 その結果,
$\mathrm{TOP}$ 群の $\mathrm{PHV}$ 年齢は $12.3 \pm 0.7$ 歳であり, BB 群 の $13.0 \pm 0.8$ 歳よりも有意に低值を示した. 本研 究と同様の方法で PHV 年齢を算出した先行研究 では, 中学生男子野球選手の PHV 年齢が $12.9 \pm$ 1.0 歳, 運動部に所属していない男子学生が 12.9 \pm 0.8 歳であり (三野・成山, 1996), 本研究の BB 群の值と同程度である. 本研究および先行研究の 結果を考慮すると, 本研究で対象とした全国大会 に出場した競技力が高い中学生投手は, 一般的な 野球選手および運動部に所属していない中学生男 子よりも身体が早熟傾向にあるといえる。また, 本研究では, 同学年内における生まれ月の相違は, 暦年齢および成熟度の個人差に影響を与える要因 であることから，対象者の生まれ月を調査した。 まず，本研究で対象とした 1995-2000 年前後に生 まれた一般日本人の生まれ月分布（3 カ月每）は， いずれも24-26\%であり, 生まれ月の偏りはほと 
んどなかった（厚生労働省（2009）から著者が算 出). 一方, 本研究の結果, 生まれ月分布は TOP 群と BB 群とで異なり, TOP 群では 4-9 月の割合 が $84 \%$ と BB 群の $56 \%$ より多く, TOP 群の 13 月生まれは $0 \%$ であった。 また, 本研究の対象 について, 生年月日から中学 3 年生 4 月 1 日の暦 年齢を算出したところ, TOP 群が 14.7 歳, BB 群 が 14.5 歳であった。本研究で対象とした選手の $\mathrm{PHV}$ 年齢と生まれ月を考慮すると, 中学 3 年生 4 月時 1 日時点において, TOP 群は BB 群よりも身 体の成熟が 0.9 歳進んでいることになる.

本研究において, 2 要因 (群間 (TOP 群, BB 群) $\times$ 年齢間 (6-14 歳)) の分散分析を行ったとこ ろ, 群間および年齢間に主効果が認められた。各 年齢の身長は, TOP 群が BB 群よりも $3-7 \mathrm{~cm}$ 高 值であった。 また, TOP 群の各年龄における身長 は, 全国平均值（6歳： $117 \mathrm{~cm}, 7$ 歳 : $122 \mathrm{~cm}, 8$ 歳：128 cm, 9 歳： $134 \mathrm{~cm}, 10$ 歳: $139 \mathrm{~cm}, 11$ 歳 : $145 \mathrm{~cm}, 12$ 歳: $153 \mathrm{~cm}, 13$ 歳: $160 \mathrm{~cm}, 14$ 歳: 166 $\mathrm{cm}$, (文部科学省, 2012) よりも 5-9 cm 高かった。 さらに, 投球スピード計測時 (中学 3 年生 8 月) の身長は, TOP 群が $173.4 \pm 5.0 \mathrm{~cm}$ であり, 19 歳の日本人の平均值の $171.7 \mathrm{~cm}$ (文部科学省, 2012）よりも高值であったことから, TOP 群の最 終身長は日本人の平均より高いと考えらえる。一 方, $\mathrm{BB}$ 群の身長は, いずれの年齢においても全 国平均值と同程度であった。 以上のことを考慮す ると, $\mathrm{TOP}$ 群が中学 3 年生 4 月時に BB 群および 全国平均值よりも身長が高值である背景には, PHV 年齢および生まれ月に伴う成熟の早さに加 えて, 就学時の身長および最終身長が高いという 遺伝的要因（水野, 1956）も影響していると考え られる。

競技力の高い選手を育成するには，スポーツ種 目にあった身体適性を備えた人材を発掘すること が重要である。日本の中でも競技人口が多く， 小・中学生期から世界大会や全国大会のために選 手の選抜が実施される野球競技では，どのような 基準で選手を選抜すべきかが大きな課題となる. 本研究の結果を考慮すると, 中学生期を対象とし た野球競技大会で活躍している選手は, 就学時の 身長が高いこと，身体の成熟が早いこと，大会時 の身長が高いこと, 生まれ月が年度切り替え日 (4
月 1 日）に近いこと，投球スピードが速いことが 挙げられる。 それらの要素は相互に関係している が，投球スピードが身長と関連していることを考 慮すると, 全国大会に出場するチームや市区町村 の選抜チームの指導者は，身体が早熟な選手また は同一学年でも身体が大きい生まれ月の早い選手 を選抜チームの選手やチームの投手として選択し ている可能性が高い。一方，各年齢における身長 の年間変化量について，2要因（群間および年齢 間）の分散分析を行ったところ，交互作用が認め られ, TOP 群の身長変化量 (中 1-中 3) は $10.7 \pm$ $3.9 \mathrm{~cm}$ であり, $\mathrm{BB}$ 群 $(17.6 \pm 5.1 \mathrm{~cm})$ よりも有 意に低值を示した。また, TOP 群の PHV 年齢が $\mathrm{BB}$ 群よりも有意に低いことを考慮すると, 高校 生以上になって身長が著しく増加する晚成型の選 手が，中学生の段階で選手としての可能性を狭め られてしまっている可能性も考えられる。実際 に, 日本のプロ野球選手における 4-9 月生まれの 割合は全体の約 $65 \%$ （岡田, 2004）であり, 相対 的年齢効果は中学生以上になっても強く残ってい る. 以上のことから, 中学生期の指導者が高校生 期以降のカテゴリーで活躍する選手を発掘・育成 するためには，成熟度および生まれ月を考慮する ことが重要と考えられる。

本研究の TOP 群で対象とした投手は, 高い競 技成績を有しているだけでなく，狙ったところに 投球する，相手に得点を与えない能力など，中学 期の野球選手の中で, 最も高い競技力を有してい ると考えられ, 発育発達研究において対象とする 意義は高いと言える。また, 本研究において対象 者の競技力を表す指標として投球スピードを計測 したところ, TOP 群の投球スピードは $34.5 \pm 1.6$ $\mathrm{m} / \mathrm{s}$ であり, BB 群 $(29.9 \pm 2.5 \mathrm{~m} / \mathrm{s})$ より有意に 高值であった（図 2)。また，使用するボールが異 なるため, 一概に比較はできないが, TOP 群の平 均值は, 大学野球選手における平均值の 33.7$35.0 \mathrm{~m} / \mathrm{s}$ (Fleisig et al., 1999 ; 勝亦ほか, 2008) と同程度であった，以上のことから，本研究で対 象とした TOP 群の選手は, 同年齢の一般野球選 手よりも高い投能力を有しており, 特に速いボー ルを投げる能力については大学生野球選手と同程 度である可能性がある。このような本研究の結果 は，スポーツ現場におけるタレントの発掘・育成 
だけでなく，発育期における投能力の発達研究に とっても基礎資料となりうる。一方，中学生期に どの程度まで投球スピードを高められるかに関し ては，使用するボールの質量および大きさを統一 した上で，体力および技術面から，詳細な検討を 行う必要がある。

野球競技は，競技力が明確な記録系の個人久 ポーツとは異なり, 投・打・走・守の各能力が必 要であるため, 競技力の定義が難しい. その中で も投能力, 特に投球スピードは定義が明確である ことから, 本研究では競技力の指標として投球ス ピードを計測した。その結果, TOP 群は BB 群よ りも有意に投球スピードが速かった. 一方, 中学 野球選手では, $50 \mathrm{~m}$ 走能力と投 (遠投)・打 (打球 スピード）との相関係数は高くないこと，体力・ 運動能力テストと野球スキルテストとの関係は, 投・打・走能力によって異なる（川口ほか, 1997) ことを考慮すると, 本研究の結果から, PHV 年齢 と打・走・守の各能力について言及することはで きない.

競技力を基準に所属チームを選択できるジュニ ア期のサッカー競技とは異なり, 本研究で対象と した中学軟式野球選手は, 一般的に近隣の中学校 の部活動で野球競技を行うため, 競技成績を事前 に予測することは難しい。 それゆえ, 本研究では, 高い競技成績を上げた選手を対象に，小学校入学 以降の一年毎の身長デー夕を収集する後ろ向き研 究を行った。本研究で用いた比例配分法は, 一年 毎の身長の值から PHV 年齢を算出するが，作図 法, 関数法に劣らない精度があることが報告され ている（松本ほか, 1988）。しかしながら, 測定の 頻度が高ければ，より詳細にPHV 年齢および身 長発育パターンの検討が可能となる。また, 本研 究では対象とした選手の最終身長を縦断的に調査 することができなかった，成熟度の指標として最 終身長, 中学期における最終身長に対する到達度 と発育パターンを検討することで，ジュニア期に 高い競技成績を上げる選手, 競技力が高い選手の 特徵がより明確になると考えられる.

本研究の結果, トップ野球選手における身体の 生物学的成熟度は, 一般の野球選手よりも進んで いることが明らかとなった。身体の生物学的成熟 度の指標とした身長および生まれ月は，いずれも
スポーツ現場で簡易に得ることができる情報であ る. また, TOP 群は BB 群よりも投球スピードが 有意に速かった，以上のことから，特に，成熟度 の個人差が大きい中学生期のスポーツ現場では, 1 年に複数回の身長測定を行い, 選手の PHV 年 齢, 身長発育パターンを早期かつ詳細に知ること が重要と考えられる。また, 本研究で計測した投 球スピードに加えて, 打・走・守の各能力を考慮 することで, 選手の選抜基準だけでなく, タレン トの発掘, トレーニング計画, ポジション適性判 断にも役立つと考えられる.

\section{$\mathrm{V}$ 結 論}

本研究は, 中学生期のトップ野球選手における 身体の生物学的成熟度について, PHV 年齢および 生まれ月の観点から検討した。本研究の結果, $\mathrm{TOP}$ 群の $\mathrm{PHV}$ 年齢は $12.3 \pm 0.7$ 歳であり, BB 群 の $13.0 \pm 0.8$ 歳よりも有意に低值を示した。ま た, 生まれ月分布は, TOP 群と BB 群とで異なり, TOP 群では 4-9 月の割合が $84 \%$ と BB 群の $56 \%$ よりも多かった. PHV 年齢と生まれ月を考慮す ると, 中学 3 年生 4 月時点において, TOP 群は $\mathrm{BB}$ 群よりも身体の成熟が 0.9 歳進んでいる可能 性があることが明らかとなった。

\section{文献}

Beunen, G., Ostyn, M., Simons, J., Renson, R., Van Gerven, D. (1981) Chronological and biological age as related to physical fitness in boys 12 to 19 years, Ann Hum Bio, 4, 321-331

Fleisig, G. S., Barrentine, S. W., Zheng, N., Escamilla, R. F., Andrews, J. R. (1999) Kinematic and kinetic comparison of baseball pitching among various levels of development, J Biomech, 32, 1371-1375 広瀬統一, 平野篤 (2008) 成長期エリートサッカー選 手の生まれ月分布と生物学的成熟度の関係, 発育 発達研究，37，17-24

比留間浩介, 尾縣貢 (2011) トレーニング方法の違い が異なる発育段階競技者の送球スピードとト レーニング効果に及ぼす影響一中学, 高校野球選 手に着目して一, 体育学研究, 56, 129-142 石田和之 (2003) 子どもの投動作の発達, 子どもと発 
育発達，1，316-319

勝亦陽一, 金久博昭, 川上泰雄, 福永哲夫（2008）投 球スピードと年齢との関係, スポーツ科学研究, 5, 224-234

川口啓太, 平野裕一, 高松薰 (1997) 日本人一流アマ チュア野球選手の体力・運動能力とスキルの発 達一中学生から社会人野球選手までの横断的観 察から一, トレーニング科学, 9, 39-46

松本健治, 三野耕, 小西博喜, 白石龍生, 吉田義昭, 武田真太郎（1988）各種の最大発育年齢算出法の 比較研究一Harpenden Growth Study の資料を用 いて一, 日本衛生学雑誌, $43,749-753$

松浦義行 (1977）学齢期の機能発達, 学校保健研究, 19, 461-464

文部科学省 (2012) 平成 23 年度体力・運動能力調查結 果の概要及び報告書

厚生労働省 (2009) 人口動態統計, 月別出生数及び死 亡数, $2-28$

三野耕, 成山公一（1996）中学生期におけるスポーツ 選手の成熟特性に関する研究, 体力科学, 45, 127-
140

水野忠文（1956）双生児の体格 - 筋力 · 運動能力の類 似度に関する研究, 東京大学教育学部紀要, 1 , $136-157$

Musch, J. and Grondin, S. (2001) Unequal competition as an impediment to personal development : a review of the relative age effect in sport, Dev Rev, 21, 147-167

Nakata, H., Nagami, T., Higuchi, T., Sakamoto, K., Kanosue, K. (2013) Relationship between performance variables and baseball ability in youth baseball players, J Strength Cond Res, 27, 28872897

Nissen, C. W., Solomito, M., Garibay, E., Ounpuu, S., Westwell, M. (2013) A biomechanical comparison of pitching from a mound versus flat ground in adolescent baseball pitchers, Sports Health, 5 , 530-536

(受付： 2016 年 6 月 8 日，受理：2016 年 9 月 14 日)
勝亦 陽一（かつまた よういち） 現職：東京農業大学応用生物科学部助教

早稲田大学大学院スポーツ科学研究科博士課程修了. 博士 (スポーツ科学).

子どもの運動能力向上, ジュニアスポーツ選手の競技能力 向上に関する実践研究，スポーツ選手に影響を与える環境 要因に関する基礎研究を行っている. 